Gut, 1961, 2, 363

\title{
The incidence and pattern of peptic ulcer in Indians and Africans in Durban
}

\author{
A E. KARK \\ From the Department of Surgery, University of Natal, South Africa
}

SYNOPSIS This paper records the hospital incidence of peptic ulcer amongst Africans and Indians in Durban and draws attention to the lower incidence amongst Africans.

Peptic ulcer symptoms are amongst the commonest complaints in Indian patients in Durban; epigastric pain related to meals, dyspepsia, and periodic exacerbations of such pain frequently form a secondary complaint when the chief complaint is referable to other parts of the body. Diseases of the stomach and duodenum, on the other hand, are relatively much less frequent in African patients.

The frequency and types of peptic ulcer among Indians and Africans admitted to this hospital in the 10-year period 1950-59 inclusive have been analysed. No separate study has been made of factors such as diet, social adjustments, or emotional stress which might influence the incidence of the disease. For comparison the incidence of peptic ulcer in White patients at Addington Hospital during a two-year period has been noted. Only those cases have been included in which a proven diagnosis of peptic ulcer has been made either at operation, necropsy, or on positive radiological evidence in association with a characteristic history of peptic ulcer or one of its complications.

Seven hundred and fifty-seven records of proven peptic ulcer were available at King Edward VIII Hospital. Six hundred and fifty-seven peptic ulcers occurred in Indians and 100 in Africans. In this period there were 65,000 Indian and 361,000 African admissions excluding maternity cases. Thus of every 1,000 Indian admissions 10.0 were for peptic ulcer while the rate per 1,000 African admissions was $0 \cdot 28$. In a two-year period at Addington Hospital of 16,230 in-patients, 183 (Table I) with peptic ulcer were admitted (11.3 per 1,000$)$.

TABLE I

INCIDENCE OF PEPTIC ULCER IN THREE RACIAL GROUPS

\begin{tabular}{|c|c|c|c|c|c|c|c|c|}
\hline \multirow[t]{2}{*}{ Race } & \multirow[t]{2}{*}{ Period } & \multirow{2}{*}{$\begin{array}{l}\text { No. of } \\
\text { Cases }\end{array}$} & \multirow{2}{*}{$\begin{array}{l}\text { Total } \\
\text { Admissions }\end{array}$} & \multirow{2}{*}{$\begin{array}{l}\text { Incidence } \\
\text { per 1,000 } \\
\text { Admissions }\end{array}$} & \multicolumn{4}{|l|}{ Ratios } \\
\hline & & & & & & Indian & African & White \\
\hline $\begin{array}{l}\text { Indian } \\
\text { African } \\
\text { White }\end{array}$ & $\begin{array}{l}(1950-59) \\
(1950-59) \\
(1957-58)\end{array}$ & $\begin{array}{l}657 \\
100 \\
183\end{array}$ & $\begin{array}{r}65,000 \\
361,000 \\
16 \cdot 230\end{array}$ & $\begin{array}{l}10 \cdot 0 \\
0.28 \\
11 \cdot 3\end{array}$ & $\begin{array}{l}\text { Male : female } \\
\text { Duodenal : gastric } \\
\text { Duodenal } \delta: q \\
\text { Gastric } \delta: q\end{array}$ & $\begin{array}{c}\text { (657 cases) } \\
8:: 1 \\
4.6: 1 \\
7: 1 \\
15.9: 1\end{array}$ & $\begin{array}{c}\text { (100 cases) } \\
8:: 1 \\
3 \cdot 5: 1 \\
6 \cdot 8: 1 \\
21: 1\end{array}$ & $\begin{array}{l}(183 \text { cases }) \\
3:: 1 \\
3.4: 1 \\
3.6: 1 \\
1.8: 1\end{array}$ \\
\hline
\end{tabular}

TABLE II

NEOPLASMS OF STOMACH IN INDIANS AND AFRICANS (1950-59)

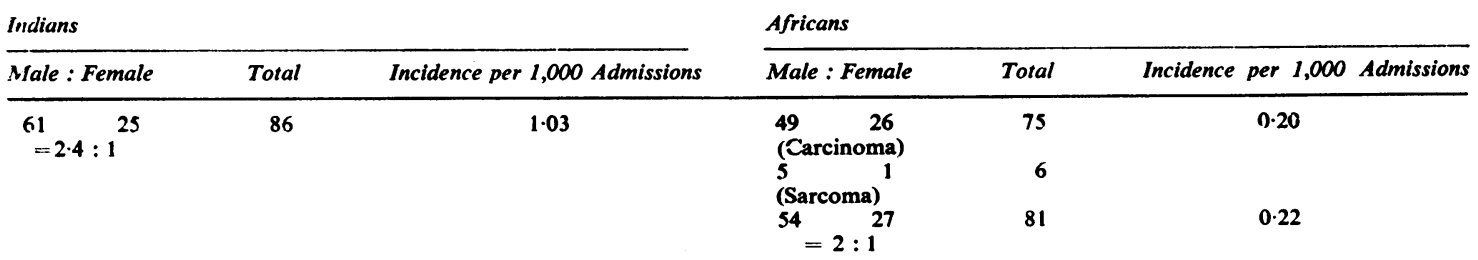




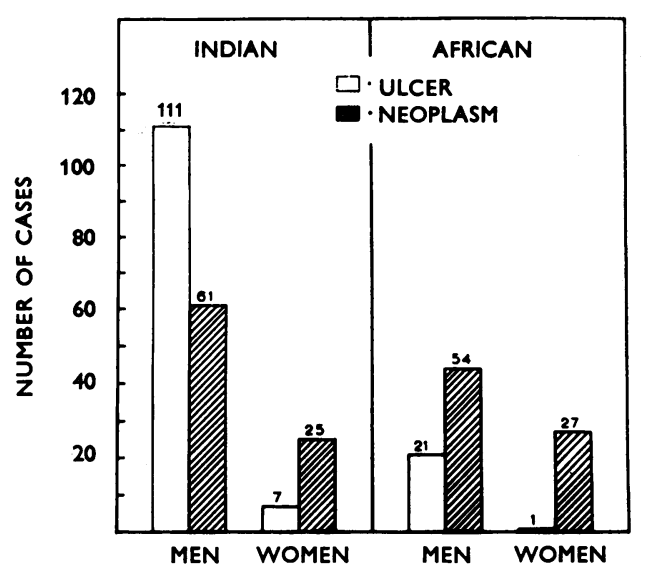

FIG. 1. Incidence of ulcer and neoplasm in the stomach in Indians and Africans.

In the same 10-year period there were admitted 86 Indians with carcinoma of the stomach, an incidence of 1.03 per 1,000 admissions, and 81 Africans with malignancy of the stomach ( 75 with carcinoma and six with lymphosarcoma), an inci- dence of 0.22 per 1,000 admissions and 0.20 when lymphosarcoma is excluded (Table II and Fig. 1).

Table I shows an analysis of the 657 Indian patients compared with the 100 Africans and 183 Whites. The ratio of duodenal ulcer to gastric ulcer was $4.6: 1$ in Indians, $3.5: 1$ in Africans, and $3 \cdot 4: 1$ in Whites. The male-to-female ratio of duodenal ulcer was $7: 1$ in Indians, 6.8:1 in Africans, and 3.6:1 in Whites (Figs. 2 and 3). The male-to-female ratio of gastric ulcer was $11.9: 1$ in Indians while in the Africans only one gastric ulcer was found in a woman. In the White hospital group this ratio was $1.8: 1$.

Table $\amalg$ and Fig. 4 analyse the incidence of perforation and haemorrhage in the three racial groups. Duodenal perforation occurred approximately as frequently in Indians as in Africans and Whites $(15.6 \% .14 \%$, and $15.5 \%)$. However, this was true for the males only. Duodenal perforation amongst Indian women was extremely uncommon, $(3 \%)$ as it was in the White group, whereas in the small group of 10 African women in two the ulcer had perforated $(20 \%)$.

The incidence of gastric perforation in men was high among Indians $(32 \cdot 4 \%)$, was common amongst
PEPTIC ULCER

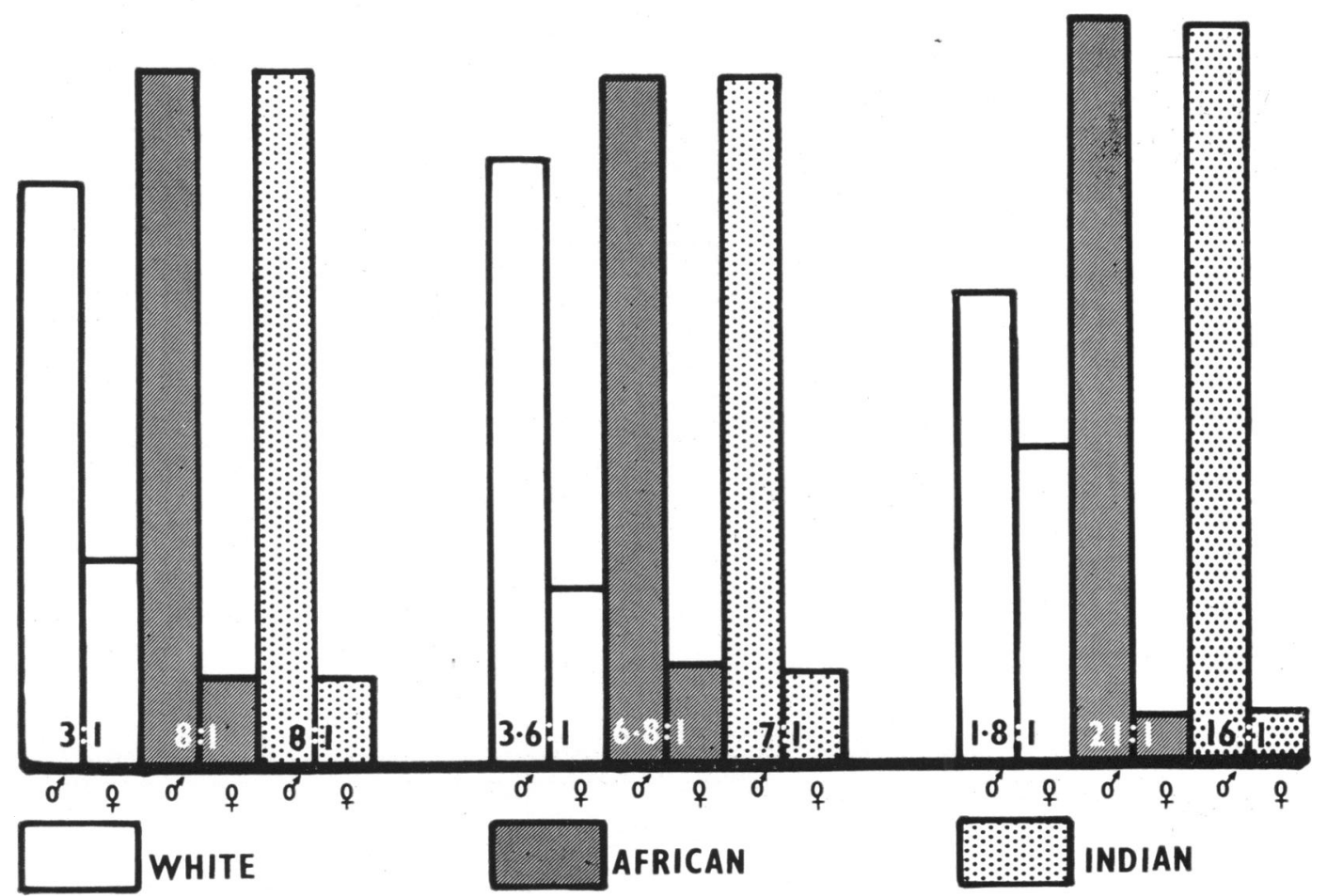

FIG. 2. Sex ratios of peptic ulcer in three racial groups. 


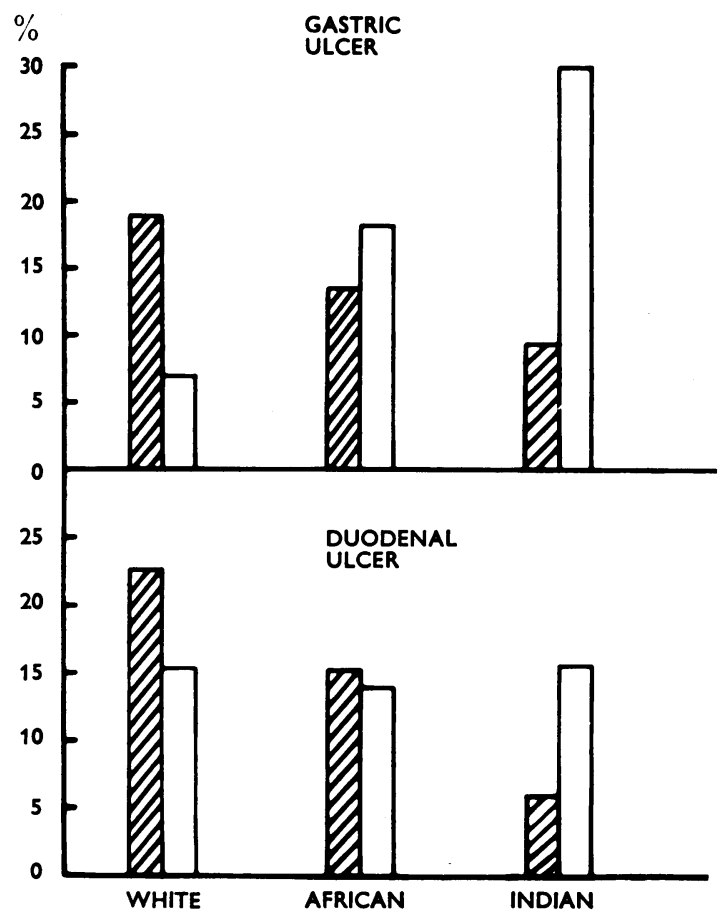

FIG. 3. Incidence of complications of peptic ulcer in three racial groups. Hatched column denotes haemorrhage, and unhatched column perforation.

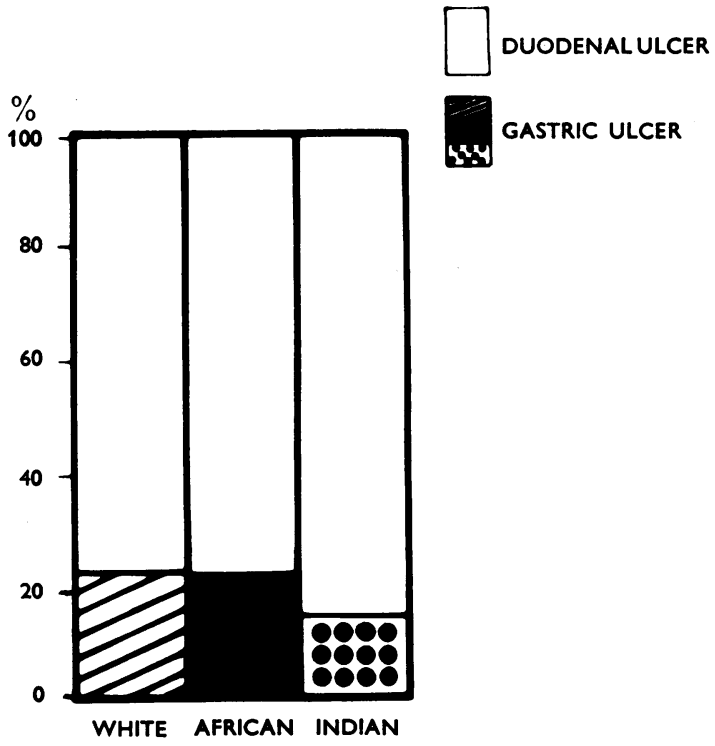

FIG. 4. Ratio of duodenal to gastric ulcer in three racial groups.
TABLE III

INCIDENCE OF COMPLICATIONS OF PEPTIC ULCER AS PERCENTAGE OF TOTAL NUMBER IN EACH GROUP

\begin{tabular}{|c|c|c|c|}
\hline & $\begin{array}{l}\text { Indians } \\
\text { (118 cases) }\end{array}$ & $\begin{array}{l}\text { Africans } \\
\text { (15 cases) }\end{array}$ & $\begin{array}{l}\text { Whites } \\
\text { (25 cases) }\end{array}$ \\
\hline Peptic perforations & $18 \cdot 0$ & 15 & $13 \cdot 6$ \\
\hline Total duodenal perforations & $15 \cdot 6$ & 14 & $15 \cdot 5$ \\
\hline o duodenal perforations & $17 \cdot 4$ & $13 \cdot 2$ & 19 \\
\hline o duodenal perforations & 3.0 & 20 & 3 \\
\hline Total gastric perforations & 30 & $18 \cdot 2$ & 7 \\
\hline o gastric perforations & 32.4 & 19 & 11 \\
\hline o gastric perforations & None & None & None \\
\hline Peptic haemorrhage & $6 \cdot 5$ & 14 & 22 \\
\hline Total duodenal haemorrhage & 5.9 & $15 \cdot 2$ & $22 \cdot 7$ \\
\hline$\delta$ duodenal haemorrhage & 6.4 & $14 \cdot 7$ & 19 \\
\hline o duodenal haemorrhage & $4 \cdot 5$ & 20 & 35 \\
\hline \multicolumn{4}{|l|}{ Total gastric ulcer } \\
\hline haemorrhage & $9 \cdot 3$ & 13.6 & 19 \\
\hline gastric ulcer haemorrhage & $9 \cdot 0$ & $14 \cdot 3$ & $18 \cdot 5$ \\
\hline o gastric ulcer haemorrhage & $14 \cdot 3$ & None & 20 \\
\hline
\end{tabular}

Africans (19\%), and less so in Whites (11\%). There were no gastric ulcer perforations in any of the women in the three groups.

The incidence of haemorrhage varied more than perforation in the three races. Both duodenal and gastric ulcers in the African male group were complicated by bleeding with approximately the same frequency $(15.2 \%$ and $13.6 \%)$. Duodenal haemorrhage occurred in two women (20\%). Amongst Indian patients haemorrhage from duodenal ulcer was relatively infrequent $(5.9 \%)$ and approximately the same in both sexes but more common from gastric ulcer $(9 \%$ and $14.3 \%$ in men and women). In White patients haemorrhage was a more frequent complication in both ulcer groups (18 to $22 \%$ ), more particularly from duodenal ulcer in women $(35 \%)$.

\section{MORTALITY}

Twenty-two deaths occurred amongst Indian patients with peptic ulcer (Table IV), five being caused by perforations found at necropsy and three patients dying from haemorrhage. These eight patients were not operated upon. The operative mortality in the Indian group was $7 \cdot 1 \%$ for curative procedures, $3.5 \%$ for closure of perforated ulcers, these four being gastric ulcers. The overall mortality was $3.7 \%$.

Eight African patients died without operation being done, four being shown at necropsy to have had perforations, three having bled, and one death being associated with a pancreatic tumour. Two $(6.9 \%)$ died following curative surgery.

The details of operative treatment of peptic ulcer in the two five-year periods are set out in Table V. 
TABLE IV

MORTALITY FROM PEPTIC ULCER (1950-59)

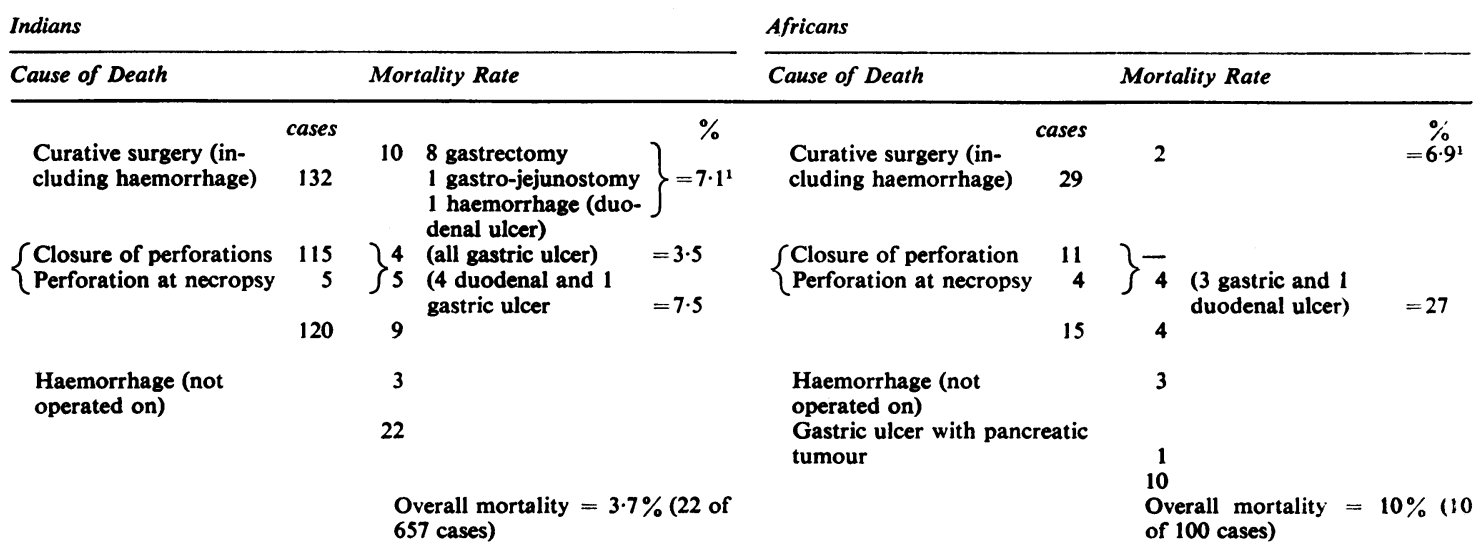

${ }^{1}$ Second five-year mortality following curative surgery $=4 \cdot 3 \%$

TABLE V

OPERATIVE TREATMENT OF PEPTIC ULCER (1950-59)

Indians

\begin{tabular}{lccc}
\hline & $\begin{array}{l}\text { Total } \\
\text { Operations }\end{array}$ & $\begin{array}{l}\text { Closure of } \\
\text { Perforation }\end{array}$ & $\begin{array}{l}\text { Curative } \\
\text { Operation }\end{array}$ \\
\hline Duodenal ulcer of & $173(24)^{1}$ & $78(16)$ & $95(8)$ \\
Duodenal ulcer o & $12(1)$ & $2(-)$ & $10(1)$ \\
Gastric ulcer of & $60(16)$ & $35(9)$ & $25(7)$ \\
Gastric ulcer o & $2(1)$ & $-(-)$ & $2(1)$ \\
Totals & $247(42)$ & $115(25)$ & $132(17)$
\end{tabular}

${ }^{1}$ The figures in brackets represent the first five-year period.

AGE

The highest incidence of duodenal ulcer among Indian males was in the 20- to 29-year group $(47.5 \%)$. Sixty-nine per cent occurred in the group aged 20 to 39 years and $83 \%$ in the group aged 20 to 49 years. Indian women had duodenal ulcer equally in the three decades 20 to 49 years, this period accounting for $75 \%$ of duodenal ulcers (Table VI).

Gastric ulcer among Indian men also occurred equally in the three decades 20 to 49 years $(77 \%$ occurring in this period). In six Indian women gastric ulcers occurred four times between the ages of 30 and 49 years and twice in the 10-to-19 age group.

Among Africans the highest incidence of duodenal ulcers in men was in the 30- to 39-year group (35\%) with $22 \%$ occurring in each of the 20 - to 29 - and 40 - to 49 -year groups, $79 \%$ occurring in the 20 - to 49- year age groups. Gastric ulcer in males also occurred most commonly in the 30 - to 39 -year group

\begin{tabular}{lccc} 
Africans & & & \\
\hline & $\begin{array}{l}\text { Total } \\
\text { Operations }\end{array}$ & $\begin{array}{l}\text { Closure of } \\
\text { Perforation }\end{array}$ & $\begin{array}{l}\text { Curative } \\
\text { Operation }\end{array}$ \\
\hline Duodenal ulcer o & $29(5)$ & $9(1)$ & $20(4)$ \\
Duodenal ulcer + & $5(1)$ & $2(-)$ & $3(1)$ \\
Gastric ulcer o & $10(2)$ & $4(1)$ & $6(1)$ \\
Gastric ulcer + & $-(-)$ & $-(-)$ & $-(1)$ \\
Totals & $49(8)$ & $15(2)$ & $29(7)$
\end{tabular}

( $47 \%), 73 \%$ occurring between the ages of 30 and 49 years.

Of the 82 duodenal perforations in Indian men, $50 \%$ occurred in the age group 20 to 29 , and of 36 gastric perforations in Indian men, $90 \%$ were equally spread over each of the three decades (20 to 49 years). The number of perforations among Indian women was too small to be analysed.

In African men six of the nine duodenal perforations occurred between the ages of 20 and 39 years, while of the four gastric perforations in men, two occurred in the 30- to 39-year age group.

The distribution of haemorrhages in age groups in each racial group was approximately the same as the frequency distribution of ulcers.

\section{DISCUSSION}

Both groups of patients of King Edward VIII Hospital are drawn from a generally poor and malnourished community. The dietary habits of Indians 
The incidence and pattern of peptic ulcer in Indians and Africans in Durban

TABLE VI

INCIDENCE OF PEPTIC ULCER IN DIFFERENT AGE GROUPS (INDIANS AND AFRICANS)

\begin{tabular}{|c|c|c|c|c|c|c|c|c|c|}
\hline & & $\begin{array}{l}\text { Age (years) } \\
0.9 \\
\text { Age (years) }\end{array}$ & $10-19$ & $20-29$ & $30-39$ & $40-49$ & $50-59$ & $60-69$ & $70-79$ \\
\hline $\begin{array}{l}\text { Indian } \\
\text { Duodenal ulcer } \\
\text { Gastric ulcer }\end{array}$ & $\begin{array}{l}\text { Male } \\
\text { Female } \\
\text { Male } \\
\text { Female }\end{array}$ & $\begin{array}{l}1(0 \cdot 2)^{1} \\
- \\
-\end{array}$ & $\begin{array}{l}26(5 \cdot 8) \\
7(11 \cdot 7) \\
5(5) \\
2(33)\end{array}$ & $\begin{array}{l}209(47 \cdot 5) \\
15(25) \\
25(25) \\
-\end{array}$ & $\begin{array}{l}95(21 \cdot 6) \\
16(27 \cdot 3) \\
28(28) \\
2(33)\end{array}$ & $\begin{array}{c}61(14 \cdot 7) \\
14(23 \cdot 3) \\
24(23 \cdot 3) \\
2(33)\end{array}$ & $\begin{array}{l}24(5 \cdot 4) \\
7(11 \cdot 6) \\
9(9) \\
-\end{array}$ & $\begin{array}{l}23(5 \cdot 2) \\
1(1 \cdot 7) \\
6(6) \\
-\end{array}$ & $\begin{array}{l}1(0 \cdot 2) \\
3(3) \\
-\end{array}$ \\
\hline $\begin{array}{l}\text { African } \\
\text { Duodenal ulcer } \\
\text { Gastric ulcer }\end{array}$ & $\begin{array}{l}\text { Male } \\
\text { Female } \\
\text { Male } \\
\text { Female }\end{array}$ & - & $\begin{array}{l}6(9 \cdot 2) \\
- \\
-\end{array}$ & $\begin{array}{l}15(22) \\
2(22) \\
2(10.5) \\
-\end{array}$ & $\begin{array}{c}24(35 \cdot 3) \\
2(22) \\
9(47) \\
1(100)\end{array}$ & $\begin{array}{r}15(22) \\
1(11) \\
5(26) \\
-\end{array}$ & $\begin{array}{l}7(10 \cdot 2) \\
3(33) \\
3(15 \cdot 8) \\
-\end{array}$ & $\begin{array}{l}1(1 \cdot 5) \\
1(11) \\
-\end{array}$ & - \\
\hline
\end{tabular}

'Percentage incidence in brackets.

and Africans have in common only a poor protein intake; generally the African subsists largely on a high carbohydrate diet, whereas the Indian eats in addition a great deal of vegetable fat.

The frequency of peptic ulcer amonst Indians is partly reflected in the figures for admissions to this hospital in a 10-year period. What is not reflected is the frequency of out-patient attendances for symptoms of peptic ulcer which are treated by diet and drugs. These represent one of the commoner complaints amongst the Indian population.

The infrequency of peptic ulcer in Africans is seen in the figures in Table I. Despite an improved hospital service by increase in staff and radiological facilities, the rate of admission of Africans with this disease has not increased out of proportion to the in-patient increase in the past five years. In the first five-year period the average annual Indian admission rate for peptic ulcer was 48 and the African seven. In the second five-year period the figures were 84 and 13 respectively; during this period there has been an increase of $80 \%$ in Indian and of $40 \%$ in African admissions. The bulk of the African patients admitted to this hospital are drawn from the urban and periurban area of Durban with a minority from outlying rural districts. In a recent hospital survey (University of Natal, 1958), $80 \%$ of all out-patients were from the Durban area; among low-paid workers, between 20 and 39 years old in five Durban industries, $55 \%$ had lived in Durban 10 years or more and only $11 \%$ had been in an urban environment for less than five years. Better paid workers and more settled family groups probably include still fewer migrant labourers and persons resident here for less than five years. While no accurate estimate has been made of the effect of work or change in diet in the series of Africans with peptic ulcer, the incidence of the condition in this area does not appear to confirm the view that the rapid urbanization of the African is reflected by an equally rapid increase of this disease (Baldachin and Palmer, 1959; Carter, 1960; Esser and Coetzee, 1960; Gelfand, 1957). What has increased is an awareness of the clinical condition in Africans; the disease has been seen sufficiently often to have impressed clinicians that it is not a rarity and must be considered in cases with upper abdominal symptoms. A considerable number of the diagnoses in the first five-year period were made at necropsy whereas latterly the overwhelming majority have been clinically confirmed.

The admission rate for patients with peptic ulcer is, however, diluted here by the large proportion of patients admitted for urgent surgery necessitated by trauma (approximately $40 \%$ of African surgical cases) as well as by a large gynaecological and paediatric unit. Thus, if these categories of patients are excluded, the incidence of admissions for peptic ulcer to general medical and surgical beds is considerably higher than those indicated, particularly amongst the Africans and to a lesser extent amongst the Indians.

The admission rate of patients with cancer of the stomach reveals an interesting difference. The incidence per 1,000 Indian admissions was 1.03 compared with a figure of 10 for peptic ulcer. The African incidence was $0.22(0.20$ excluding sarcomata), almost the same as for ulcer $(0 \cdot 28)$. Thus cancer of the stomach occurred almost as frequently as peptic ulcer in Africans in this area, whereas in Indians it occurred eight times less frequently. The incidence of gastric ulcer and gastric neoplasm in the two racial groups is seen in Fig. 1. There was a considerably higher rate of cancer in both African sexes and in Indian women but not in Indian men. Of the malignancies occurring in Africans, $7.5 \%$ were lymphosarcomata. Despite the difference in admission rates for the two races to this hospital and 
those reported by Esser and Coetzee (1960), the figures show a similar trend.

Peptic ulcer in Indians is a disease predominantly seen in the early twenties, many patients having histories dating from their teens. In the African the peak incidence of duodenal and gastric ulcer is in the 30- to 39-year group. The incidence of complications of peptic ulcer in Indians is strikingly different from that of the White population and of the Africans. In the Indian group $17.4 \%$ of male patients with duodenal ulcers and $32.4 \%$ of male patients with gastric ulcers were admitted for perforation. Duodenal perforations in women were a rarity and no gastric ulcers in women have been seen with perforation. Haemorrhage, on the other hand, is not a common complication in the Indian group (5.6\% in duodenal ulcers and $10 \%$ in gastric ulcers in men) while in a small group of women the corresponding figures were a little higher ( $4 \cdot 5 \%$ and $14 \cdot 3 \%)$. Pyloric stenosis in varying degree is a frequent complication.

Fourteen per cent of duodenal ulcers in African men are perforated and $\mathbf{1 5 . 2} \%$ caused haemorrhage. Of gastric ulcers in African men, $18.2 \%$ had perforated and $14.3 \%$ had bled. A small series of duodenal ulcers in African women showed that $20 \%$ had perforated and $20 \%$ had bled. There was only one gastric ulcer in African women, a large crater in the lesser curvature which at operation appeared to be inoperable carcinoma but at necropsy was shown to be a peptic ulcer. The rarity of gastric ulcer in African women is also borne out in the series of 58 ulcers reported by Esser and Coetzee (1960) who found only one in this group. With the exception of gastric ulcer in women these figures for the complications of ulcer in Africans accord more closely with those for White patients in this area (Fig. 4).

In discussing the incidence of peptic ulcer or any other disease among black people the use of the word 'African' may be as misleading as the use of the word 'European' on the Continent of Europe. The types of people in southern and central Africa differ in their physique, state of health, degree of education, and city living and dietary habits no less than those extending in Europe from Spain to Scandinavia. Moreover, the bulk of the medical and surgical conditions in an African general hospital in the Union as well as in other parts of Africa, comprise trauma, sepsis, malnutrition, tuberculosis, amoebiasis, and acute pulmonary infections; until these conditions cease to be the overwhelming public health and social problems that they are, and therefore their victims cease overcrowding the hospitals, the non-tropical diseases of well-nourished people must perforce be relegated to a position of secondary importance except in severe cases.
Raper (1958) has shown the high necropsy incidence of ulcer in Uganda, where Shaper and Williams (1959) agree that ulcer is a well-recognized clinical entity; although usually occurring in the labouring and farming people it is a not infrequent diagnosis in university students (19 of 400 students). Konstam (1954) and others (Joly, 1956) have repeatedly pointed out the frequency of peptic ulceration in West Africa. Humphries (1959), on the other hand, points out the rarity of ulcer in Nyasaland.

In Sierra Leone, Carter (1960) and Baldachin and Palmer (1959) comment on their impression of the increasing frequency of peptic ulcer among those African groups whose standard of living has increased.

In South Africa, Eagle and Gillman (1938) noted the rarity of ulcer at necropsy in Africans in Johannesburg; Charlewood and Frylinck (1951) reported an $0.09 \%$ incidence in non-White hospitals in Johannesburg, and McKenzie (1957) an incidence in a two-year period at King Edward VIII Hospital in Durban of $0.068 \%$. The incidence of $0.025 \%$ of hospital admissions in the present series is still lower; in the first five-year period the admission rate was $0.021 \%$ and in the second five-year period only $0.03 \%$.

The ratio of duodenal to gastric ulcer here is $3 \cdot 3: 1$, similar to the ratio for White and Indian patients. The rarity of gastric ulcer among Africans reported by Ellis (1948) and Joly (1956) in Nigeria, and Shaper and Williams (1959) and Raper (1958) in Uganda, is borne out in women in Durban where only a single case has been seen; 21 of 22 gastric ulcers occurred in men.

The sex ratio of peptic ulcer varies in different parts of Africa. In Nigeria, Ellis (1948) reported a 9.3: 1 ratio for duodenal ulcers whereas Aitken (1933) reported a $12: 1$ ratio and Joly (1956) one of $3.7: 1$. The present series shows a $8: 1$ ratio, being $6 \cdot 8: 1$ for duodenal ulcer and $21: 1$ for gastric ulcer. These figures are all uncorrected for the admission rate of men and women, which, in this hospital, is approximately $1.6: 1$. The corrected rate here for duodenal ulcer is $3 \cdot 6: 1$.

The incidence of the complications of peptic ulcer throughout Africa appears to vary widely (Kark, 1959). In Nigeria (Joly, 1956), haemorrhage and perforations occur in $2 \%$ and $0.1 \%$ of cases respectively. This is the same pattern as in India (Somervell and Orr, 1936) where the figures are $0.1 \%$ and $1 \%$, and among the Swahili of Zanzibar (Vassallo, 1937). The White patients in the Union suffer the complications with about the same frequency as do those in Britain; the Indians have a low incidence of haemorrhage and a high incidence of perforation; the Africans in Durban have an 
overall rate of perforation and bleeding not dissimilar to that of the Whites, notable differences being the considerably higher rate of gastric perforations in men and the rarity of gastric ulcer and therefore its complications in women.

\section{OPERATIVE TREATMENT}

Table IV summarizes the mortality following emergency and elective surgery for peptic ulcers. The increase in elective operations reflects the increase in staff and facilities. The mortality for curative surgical operations, including those for haematemesis, was $7 \cdot 1 \%$ and $6.9 \%$ in Indians and Africans respectively. This high figure is partly accounted for by the considerable overcrowding and inadequate nursing and medical personnel during the first five-year period; in the second five-year period the mortality for elective surgery was $4.3 \%$ (six of 137 cases) and in 1959 was $1.6 \%$ (one of 62 cases). Table $V$ compares the surgical treatment in the first five-year period with that in the second five-year period.

\section{SUMMARY}

The hospital incidence of peptic ulcer in Africans and Indians in Durban has been analysed. The material includes 757 proven cases admitted during 1950-59. The admission rate has been compared with the incidence of neoplasm of the stomach in each group (167 cases). For comparison a two-year incidence of peptic ulcer in Whites has been included (186 cases).

The peak age incidence for Indians with duodenal ulcer is 20 to 29 years and for Africans 30 to 39 years.

Attention is drawn to the low incidence of peptic ulcer in Africans, with the reservation that the figures must be viewed in relation to a total admission rate comprising cases mostly of trauma, of sepsis, and of acute infection.

Gastric ulcer in Indians is very uncommon and in women is rare; gastric ulcer in Africans is also very seldom seen, and, as in Indians, is rare in women, in White women it occurs half as frequently as in men.

There is a low incidence of duodenal perforation in women in all three racial groups, the African figure of $20 \%$ only representing two cases.
No gastric ulcer perforated in women in any of the three groups.

Haemorrhage complicating peptic ulcer is uncommon in the Indian group compared with the relatively high incidence in Africans and Whites. In this respect the low incidence in Indians is in close accord with the rarity of this complication in South India and in Nigeria. In Indians gastric ulcers appear more likely to bleed than do duodenal ulcers.

The mortality following elective and emergency surgery is briefly analysed.

Thanks are due to Mr. Z. Ndlovu and Mr. M. Moodley, technicians. The medical superintendants, Dr. S. Disler and Dr. Tanchel, kindly permitted the use of case records.

This work was undertaken during the tenure of a grant made available by the National Cancer Association of South Africa, and thanks are due to Mr. C. J. Lockett, working under the auspices of the Association.

\section{REFERENCES}

Aitken, A. B. (1933). Remarks on peptic ulcer. W. Afr. med. J., 6, 6365.

Baldachin, B. J., and Palmer, P. E. S. (1959). Peptic ulcer in Africans. Brit. med. J., 2, 304

Carter, F. S. (1960). Ibid, 1, 505-506.

Charlewood, G. P., and Frylinck, R. (1951). Some discrepancies in disease incidence between the European and the South African negro (Bantu). S. Afr. med. J., 25, 551-556.

Eagle, P. C., and Gillman, J. (1938). The incidence of peptic ulcer in the South African Bantu. S. Afr. J. med. Sci., 3, 1-6.

Ellis, M. (1948). A study of peptic ulcer in Nigeria. Brit. J. Surg., 36, 60-65.

Esser, H. R., and Coetzee, T. (1960). Peptic ulcer in Indians and Africans in Natal. Med. Proc., 6, 153-158.

Gelfand, M. (1957). The Sick African, 3rd ed. Juta, Cape Town.

Humphries, S. V. (1959). Peptic ulcer in Africans. Brit. med. J., 2, 1253.

Joly, B. M. (1956). Peptic ulcer in Western Nigeria and Southern United States. W. Afr. med. J., n.s. 5, 55-63.

Kark, A. E. (1959). Aetiology and demography of peptic ulcer, Leech, 29, 117-130.

Konstam, P. G. (1954). Peptic ulcer in Southern Nigeria. Lancet, 2, 1039-1040.

McKenzie, M. B. (1957). Peptic ulceration in the African of Durban. S. Afr. med. J., 31, 1041-1045.

Raper, A. B. (1958). The incidence of peptic ulceration in some African tribal groups. Trans. roy. Soc. trop. Med. Hyg., 52, 535-546.

Shaper, A. G., and Williams, A. W. (1959). Peptic ulcer in Africans. Brit. med J., 2, 757-758.

Somervell, T. H., and Orr, I. M. (1936). Some contributions to the causation, pathology, and treatment of duodenal ulcer and its complications. Brit. J. Surg., 24, 227-245.

Vassallo, S. M. (1937). Duodenal ulcer in Zanzibar. E. Afr. med. J., $14,83-88$.

University of Natal (1958). Department of Social and Preventive and Family Medicine: A Study of the King Edward VIII Hospital Out-Patient Service. 